УДК 343.241

DOI https://doi.org/10.32849/2663-5313/2020.5.48

Анастасія Хильченко (Макаренко), канд. юрид. наук, дочент кафедри кримінального права

Національного університету «Одеська юридична академія»

\title{
ДЕЯКІ ПИТАННЯ ПРИЗНАЧЕННЯ ПОКАРАННЯ НА ПІДСТАВІ УГОД
}

У цій статті висвітлюються питання призначення покарання у разі укладення та затвердження угод про примирення або про визнання вини. Виділяється проблема дискреиійності кримінально$2 о$ закону, шо полягає у тому, наскільки широким має бути суддівський розсуд у вирішенні питань кримінально-правового характеру. Надається визначення суддівського розсуду, зазначаються підстави його існування. Пропонується підставами суддівського розсуду під час призначення покарання вважати кримінально-правові санкиї, передбачені чинним Кримінальним кодексом Украӥни, уповноважуючі норми, юридичні факти, що об'єктивуються в юридичних термінах і поняттях, та правила індивідуалізачї̈ покарання. Це має велике значення для удосконалення вітчизняної законодавчої техніки та редагування правил призначення покарання за наявності угод про примирення або про визнання вини. Встановлено, шо приватний інтерес, будучи домінантою у кониепиї угод про примирення, врешті не елімінував дискреційність повноважень суддів у виборі міри кримінально-правового впливу. Правило про обов'язковість призначення покарання, вказаного в угоді про примирення, спростовується повноваженням суддів здійснювати правовий аналіз консенсуального рішення і можливістю не затверджувати угоду у встановлених випадках. Автором розглядаються проблеми укладення угод про примирення або про визнання вини щодо злочинів, пов'язаних з домашнім насильством, у разі призначення покарання за сукупністю злочинів та сукупністю вироків, а також про можливість укладення та затвердження таких угод щодо двооб'єктних (багатооб'єктних) злочинів. Аналізується чинне кримінальне законодавство, а також практика його застосування. Зроблені відповідні зауваження та висновки щодо необхідності оптимізації вітчизняного механізму кримінально-правового регулювання з урахуванням тендениій у практиці застосування кримінального закону. Особлива увага приділена проблемі конкретизащї правил призначення покарання, а також необхідності розробки правил призначення інших заходів кримінально-правового характеру. Встановлено, що керуюча роль практики вищих судових інстанцій демонструє та надає базис для переосмислення, конкретизаиї та інколи оновлення правил призначення покарання в окремих (спечіальних) випадках.

Ключові слова: суддівський розсуд, сукупність злочинів, сукупність вироків, домашне насильство, двооб'єктні злочини.

Постановка проблеми. Законом України від 13.04.2012 № 4652-VI «Про внесення змін до деяких законодавчих актів у зв'язку 3 прийняттям Кримінального процесуального кодексу України» [9] стаття 65 Кримінального кодексу України (далі - КК України) доповнена частиною п'ятою такого змісту: «У випадку затвердження вироком угоди про примирення або про визнання вини суд призначає покарання, узгоджене сторонами угоди». Стаття 75 КК України після частини першої доповнена новою частиною такого змісту: «2. Суд приймає рішення про звільнення від відбування покарання 3 випробуванням у випадку затвердження угоди про примирення або про визнання вини, якщо сторонами угоди узгоджено покарання у вигляді виправних робіт, службового обмеження для військовослужбовців, обмеження волі, позбавлення волі на строк не більше п'яти років, а також узгоджено звільнення від відбування покарання з випробуванням». У зв'язку із введенням таких норм виникло багато питань прикладного характеру, вирішення яких не має єдності поглядів у доктрині так само, як і викликає труднощі у практиці застосування.

Аналіз останніх досліджень і публікацій. Науковий інтерес до вивчення кримінально-правових аспектів інституту угод у разі призначення покарання має місце, звичайно, у тих учених, які займаються аналізом проблем покарання та його призначення, а також принципом диспозитивності кримінально-правового регулювання Особливо відзначимо таких науковців, як П.П. Андрушко, М.М. Васюк, М.І. Витязь, Р.Ш. Бабанли, О.В. Євдокимова, А.А. Музика, В.В. Навроцька, О.М. Поліщук (Шостак), 
Є.Л. Стрельцов, В.І. Тютюгін, В.О. Туляков, С.О. Ященко. Однак динамічність суспільних відносин, внесення змін до законодавства, переорієнтація вітчизняної кримінальної юстиції на судову практику як джерело права, проблеми, що виникають у казуальній практиці застосування кримінального закону, вимагають переосмислення та своєчасного дослідження та аналізу інституту призначення покарання крізь призму угод.

Мета статті. Звичайно, проблемні аспекти інституту угод неможливо розкрити в одній публікації, тому дискусійні моменти відповідного інституту ми розкривали свого часу у попередніх публікаціях. Метою цієї статті є виділення проблем, що виникають під час укладення та затвердження угод про примирення або визнання вини щодо злочинів, пов'язаних з домашнім насильством, під час призначення покарання за сукупністю злочинів та сукупністю вироків, а також про можливість укладення таких угод щодо двооб'єктних злочинів.

Виклад основного матеріалу дослідження. Правовою базою у вивченні цього питання, крім КК України та Кримінального процесуального кодексу України (далі КПК України), виступають: Закон України «Про внесення змін до деяких законодавчих актів у зв'язку з прийняттям Кримінального процесуального кодексу України» № 4652-VI від 13.04.2012 [9]; Закон України «Про запобігання та протидію домашньому насильству» № 2229-VIII від 07.12.2017 р. [10]; Закон України «Про внесення змін до Кримінального та Кримінального процесуального кодексів України з метою реалізації положень Конвенції Ради Свропи про запобігання насильству стосовно жінок і домашньому насильству та боротьбу з цими явищами» № № 2227-VIII від 06.12.2017 р. [11]; Постанова Пленуму Верховного Суду України від 24.10.2003 р. № 7 «Про практику призначення судами кримінального покарання» [12]; інформаційний лист Вищого спеціалізованого суду України з розгляду цивільних і кримінальних справ від 15.11.2012 № 2231679/0/4-12 «Про деякі питання здійснення кримінального провадження на підставі угод» [13]; лист Вищого спеціалізованого суду України з розгляду цивільних i кримінальних справ від 05.04.2013 р. № 223-558/0/4-13 «Про доповнення до інформаційного листа Вищого спеціалізованого суду України 3 розгляду цивільних і кримінальних справ від 15.11.2012 № 223-1679/0/4-12 «Про деякі питання здійснення кримінального провадження на підставі угод» [14]; Постанова Пленуму
Вищого спеціалізованого суду України з розгляду цивільних і кримінальних справ від 11.12.2015 № 13 «Про практику здійснення судами кримінального провадження на підставі угод» [15]; правові позиції Верховного Суду України.

Відповідно до ч. 5 ст. 65 КК України за наявності угоди про примирення або про визнання вини суд призначає узгоджену сторонами міру покарання. У такому разі ми зіштовхуємося з так званим «делегованим правосуддям», коли традиційно публічну функцію з вирішення суспільних конфліктів у формі відправлення правосуддя, що пов'язана з існуванням судового складника державної влади, передано на розсуд особам, які професійно не наділені такими повноваженнями. Як зазначає Р.Ш. Бабанли, у системі координат, у межах яких у вітчизняному правосудді призначається покарання, з'явилась фактично незалежна від суду координата, яка виключає участь суду в обранні виду та розміру покарання, і уповноважує його лише відобразити в обвинувальному вироку той вид та розмір покарання, який погодили сторони угоди [1, с. 328].

На нашу думку, інститут призначення покарання за наявності угод про примирення або про визнання вини не $є$ формалізованим. За задумом законодавця право сторін на узгодження міри покарання має обмежувати дискреційні повноваження суддів, однак не ставить сам пеналізаційний процес у певні рамки. Склалася ситуація, коли правозастосовний розсуд змінив свого суб'єкта. А саме обмеження суддівського «розсудового» елементу не являє собою формалізованої системи врахування обставин у кримінальному провадженні [6]. Справді, у процесі реформування кримінального законодавства України часто ставиться питання, наскільки широкою має бути суддівська дискреція та які наслідки це має для ефективності застосування заходів кримінально-правового характеру. Тому, очевидно, завжди для вивчення того чи іншого питання, що стосується застосування покарання, доцільним постає встановлення оптимуму співвідношення формальних та дискреційних засад. Так, нами було запропоновано розуміти суддівський розсуд у кримінальному праві як правозастосовчу інтелектуально-вольову діяльність судді, яка $є$ передбаченою кримінальним законом мірою свободи вибору одного з варіантів рішення у кримінальному провадженні [5, с. 18]. Крім цього, було виділено його підстави як нормативну основу здійснення. Так, підставами суддівського розсуду під час призначення покарання є кримінальноправові санкції, передбачені чинним КК, 
уповноважуючі норми, юридичні факти, що об'єктивуються в юридичних термінах і поняттях, та правила індивідуалізації покарання [5, с. 74].

У постанові колегії суддів Другої судової палати Касаційного кримінального суду у складі Верховного Суду зазначено, що поняття судової дискреції (судового розсуду) у кримінальному судочинстві охоплюе повноваження суду (права та обов'язки), надані йому державою, обирати між альтернативами, кожна з яких є законною, інтелектуально-вольовою владною діяльністю суду з вирішення у визначених законом випадках спірних правових питань, виходячи із цілей та принципів права, загальних засад судочинства, конкретних обставин справи, даних про особу винного, справедливості й достатності обраного покарання тощо. Підставами для судового розсуду під час призначення покарання виступають: кримінально-правові, відносно визначені (якими встановлюються межі покарання) та альтернативні (якими передбачено декілька видів покарань) санкції; принципи права; уповноважуючі норми, в яких використовуються щодо повноважень суду формулювання «може», «вправі»; юридичні терміни та поняття, які є багатозначними або не мають нормативного закріплення, зокрема «особа винного», «щире каяття» тощо; оціночні поняття, зміст яких визначається не законом або нормативним актом, а правосвідомістю суб'єкта правозастосування, наприклад, у разі врахування пом'якшуючих та обтяжуючих покарання обставин (статті 66, 67 КК), визначення «інших обставин справи», можливості виправлення засудженого без відбування покарання, що має значення для застосування ст. 75 КК тощо; індивідуалізація покарання - конкретизація виду і розміру міри державного примусу, який суд призначає особі, що вчинила злочин, залежно від особливостей цього злочину і його суб'єкта (постанова колегії суддів Другої судової палати ККС ВС від 22 березня 2018 року у справі № 207/5011 /14-к, провадження № 51-1985 км 18) [8]. У разі дослідження угод про примирення або визнання вини підставою для наявності розсуду певного суб'єкта та обмеження судового як раз i виступають уповноважуючі/зобов'язуючі норми права. Як нами вже було відзначено, що правило про обов'язковість призначення покарання, вказаного в угоді, спростовується повноваженням суддів здійснювати правовий аналіз консенсуального рішення і можливістю не затверджувати угоду у встановлених випадках.

Одна 3 проблем, що виникають під час затвердження угод, полягає у тому, чи мають право сторони узгоджувати остаточну міру покарання за сукупністю злочинів (ст. 70 КК України) та сукупністю вироків (ст. 71 КК України)? Так, аналіз норм гл. 35 КПК України свідчить, що угода про примирення або визнання вини може бути укладена під час вчинення підозрюваним/обвинуваченим не тільки одного, але і декількох злочинів, зазначених у ч. 3 і ч. 4 ст. 469 КПК України. Відповідно до абз. 2 ч. 3 ст. 475 КПК України у резолютивній частині вироку на підставі угоди має міститися рішення про затвердження угоди із зазначенням її реквізитів, рішення про винуватість особи із зазначенням статті (частини статті) закону України про кримінальну відповідальність, рішення про призначення узгодженої сторонами міри покарання за кожним з обвинувачень та остаточна міра покарання, а також інші відомості, передбачені статтею 374 КПК України.

П. 20 Постанови Пленуму ВССУ № 13 від 11.12.2015 «Про практику здійснення судами кримінального провадження на підставі угод» встановлює, якщо ж суд переконається в тому, що угоду може бути затверджено, то відповідно до ст. 475 КПК він ухвалюе вирок, яким затверджує угоду і призначає узгоджену сторонами міру покарання. У разі коли кримінальне провадження у зв'язку 3 укладенням угоди попередньо було виділено в окреме провадження, потім вироком суду затверджено угоду та призначено узгоджене між сторонами покарання чи звільнення від його відбування з випробуванням, при цьому щодо інших кримінальних правопорушень провадження здійснювалось у загальному порядку, то під час визначення остаточного покарання суд має керуватися ч. 4 ст. 70 та ст. 72 КК [15]. Якщо ж підозрюваний чи обвинувачений у період відбування покарання за вчинене кримінальне правопорушення вчинив інше кримінальне правопорушення, у провадженні щодо якого надалі було укладено угоду, суд, переконавшись, що угода може бути затверджена, ухвалює вирок, яким затверджує угоду, призначає узгоджену сторонами міру покарання, а остаточне покарання визначає, керуючись правилами статей 71, 72 КК [15].

Відповідно до п. 23 Постанови ПВСУ від 24.10.2003 р. № 7 «Про практику призначення судами кримінального покарання» у разі визнання особи винною у вчиненні кількох злочинів рішення про їі звільнення від відбування покарання 3 випробуванням приймається тільки після визначення на підставі частини 1 статті 70 КК остаточного покарання, виходячи з його виду й розміру [12]. Здійснюючи системне тлумачення таких приписів, можна відзначити, що під 
час затвердження угод призначення остаточного покарання із застосуванням ч. 4 ст. 70, ст. ст. 71 та 72 КК України є прерогативою суду.

Виходячи 3 природи інституту сукупності злочинів та сукупності вироків, системного тлумачення законодавства, а також практики його застосування, зокрема, «позитивної» та такої, коли суди повинні були призначати покарання у порядку ст. ст. 71, 72 КК України [2; 3; 4 та ін.], однак не призначали, позаяк вважали, що це є предметом угоди, можемо зробити такі зауваження: 1) призначення остаточного покарання із застосуванням ст. 70 КК України може бути узгоджено в угоді, окрім ситуації, встановленої ч. 4 ст. 70 КК України; 2) призначення остаточного покарання із застосуванням ст. ст. 71 та 72 КК України є компетенцією суду та не може бути врегульовано в угоді. Ст. 71 КК України містить імперативну норму про призначення покарання за сукупністю вироків виключно судом.

Вважаємо, що конкретизація правил призначення покарання у разі сукупності злочинів та сукупності вироків за наявності угод про примирення або про визнання вини повинна бути чітко врегульована кримінальним законом.

Наступне. Відповідно до абз. 2 ч. 1 ст. 469 КПК України «угода про примирення у кримінальних провадженнях щодо злочинів, пов'язаних з домашнім насильством, може бути укладена лише за ініціативою потерпілого, його представника або законного представника». Згідно зі статею $91^{-1} \mathrm{KK}$ України «Обмежувальні заходи, що застосовуються до осіб, які вчинили домашне насильство» в інтересах потерпілого від злочину, пов'язаного з домашнім насильством, одночасно з призначенням покарання, не пов'язаного з позбавленням волі, або звільненням $з$ підстав, передбачених цим Кодексом, від кримінальної відповідальності чи покарання, суд може застосувати до особи, яка вчинила домашнє насильство, один або декілька обмежувальних заходів, відповідно до якого (яких) на засудженого можуть бути покладені такі обов'язки. Можемо відзначити такі зауваження та дискусійні питання: 1) обмежувальні заходи, передбачені КК України до осіб, які вчинили домашне насильство, не $є$ альтернативою покарання; 2) це є дискрецією суду призначити обмежувальні заходи у разі скоєння злочину, пов'язаного $з$ домашнім насильством. Питання: чи можуть такі заходи бути предметом угоди? Системний аналіз КК України та практики його застосування (що є предметом окремого дослідження) у тому числі крізь призму «інших заходів» свідчить, що предметом угод виступає лише покарання або звільнення від його відбування із застосуванням ст. 75 КК. Інші заходи призначаються виключно судом; 3) правила (засади) призначення інших заходів, у тому числі й обмежувальних (Р. XIII-1 КК України), не встановлені КК України. Як відомо, ст. 65 КК України регламентує лише правила визначення покарання, у тому числі й у разі затвердження угод (ч. 5 ст. 65). Ст. 75 КК України подібним чином встановлюе правила звільнення від відбування покарання, а не інших заходів. Як висновок, питання призначення інших заходів кримінально-правового характеру, у тому числі під час укладення та затвердження угод, повинні бути належним чином урегульовані КК України.

Ще однією проблемою, яку ми хочемо розглянути у цій статті, є питання можливості укладення угод про примирення щодо двооб'єктних злочинів.

Лист ВССУ від 05.04.2013 р. № 223558/0/4-13 «Про доповнення до інформаційного листа Вищого спеціалізованого суду У країни з розгляду цивільних і кримінальних справ від 15.11.2012 № 223-1679/0/4-12 «Про деякі питання здійснення кримінального провадження на підставі угод» встановлює, що, вирішуючи питання про те, чи підлягає затвердженню судом угода про примирення, якщо одним і тим самим злочином завдано одночасно шкоди потерпілому і державним чи суспільним інтересам, слід враховувати не лише положення ч. 3 ст. 469 КПК, а й специфіку об'єкта посягання та характер охоронюваних кримінальним законом благ [14].

Зокрема, дотримуючись вимог, встановлених ч. 3 ст. 469 КПК, щодо укладення угод про примирення, укладаючи угоду про примирення, слід враховувати, що така угода може бути укладена тільки у випадках, коли кримінальне правопорушення завдає шкоди приватним інтересам (інтересам фізичної особи) та/або майновим інтересам юридичної особи, тобто лише щодо діянь, які посягають на приватні інтереси та не зачіпають значною мірою публічних інтересів. У злочинах, де основним безпосереднім об'єктом виступають публічні інтереси (зокрема, немайнові), а спричинена конкретним фізичним чи юридичним особам шкода є лише проявом посягання на основний об'єкт, укладення угоди про примирення не допускається. Однак судова практика встановила таке правоположення. Так, колегія суддів Першої судової палати Касаційного кримінального суду у складі Верховного Суду зробила висновок, визначаючи, чи можна укладати угоди про примирення між потерпілим та обвинуваче- 
ним щодо двооб'єктних (багатооб'єктних) злочинів, суд має не тільки керуватися вимогами статей 468, 469, 474 Кримінального процесуального кодексу України, а й установити, чи не суперечить зміст такої угоди інтересам суспільства та чи забезпечений баланс інтересів сторін угоди про примирення. Вироком суду першої інстанції, який апеляційний суд залишив без змін, була затверджена угода про примирення, укладена між потерпілим і на той час підозрюваним. Чоловік був визнаний винним у скоєнні злочину, передбаченого ч. 2 ст. 345 Кримінального кодексу України (погроза або насильство щодо працівника правоохоронного органу). ВС погодився 3 висновками судів першої та апеляційної інстанцій про те, що зміст укладеної угоди про примирення жодним чином не суперечить інтересам суспільства; в ній повною мірою забезпечено баланс інтересів сторін угоди про примирення для цілей норм ч. 3 ст. 469, п. 7 ст. 474 КПК України. ВС не встановив обгрунтованих підстав обмежувати дію принципу диспозитивності в цій конкретній категорії проваджень [7]. Виходячи $з$ цього, під час укладення угод про примирення щодо двооб'єктних злочинів, враховуючи правові позиції Верховного Суду, можна виділити такі критерії їх укладення та затвердження: 1) закон; 2) інтереси суспільства; 3) забезпечення балансу інтересів сторін про примирення. Така позиція Верховного Суду ще раз підкреслює зростання диспозитивних засад у разі застосування заходів кримінально-правового характеру та переорієнтацію кримінальної юстиції на забезпечення врахування інтересів усіх учасників кримінального провадження. Сформування Верховним Судом таких критеріїв $є$ важливим для конкретизації правил, що застосовуються у пеналізаційному процесі.

\section{Висновки}

Резюмуючи, важливо відзначити, що необхідним є подальше вивчення та удосконалення кримінально-правового механізму реагування на вчинені правопорушення шляхом балансу співвідношення формальних та дискреційних засад під час введення нового інституту та його застосування на практиці. Крім цього, будь-яка нова норма та їі апробація вимагає забезпечення системності всіх без винятків раніше встановлених концептів. Керуюча роль практики вищих судових інстанцій демонструє та надає базис для переосмислення, конкретизації та інколи оновлення правил призначення покарання у спеціальних випадках, регламентації правил призначення інших заходів кримінально-правового характеру, а також для детальної розробки критеріїв визначення міри кримінально-правового впливу в окремих (спеціальних) випадках.

\section{Список використаних джерел:}

1. Бабанли Р.Ш. Призначення покарання в Україні: теоретико-прикладні засади. Чернігів : Десна Поліграф, 2019. 488 с.

2. Єдиний реєстр судових рішень. Справа № 336/482/18. URL: http://reyestr.court.gov.ua/ Review/80878723.

3. Єдиний реєстр судових рішень. Справа № 127/13204/19. URL: http://reyestr.court.gov. ua/Review/87274663.

4. Єдиний реєстр судових рішень. Справа № 485/1606/19. URL: http://reyestr.court.gov.ua/ Review/84796493.

5. Макаренко А.С. Суддівський розсуд при призначенні покарання в Україні : монографія Одеса : Юридична література, 2013. 272 с.

6. Макаренко (Хильченко) А.С. Проблема дискреційності кримінального закону крізь призму угод про примирення. Часопис иивільного $і$ кримінального судочинства. № 3 (18) 2014. C. $106-115$.

7. Постанова колегії суддів Другої судової палати ККС ВС від 22 березня 2018 року у справі № 207/5011 /14-к, провадження № 51-1985 км 18. URL: http://reyestr.court.gov.ua/ Review/73001386.

8. Постанова колегії суддів Першої судової палати ККС ВС від 6 грудня 2018 року у справі № 756/11661/17, провадження № 51-4582 км 18. URL: http://reyestr.court.gov.ua/ Review/78496216.

9. Про внесення змін до деяких законодавчих актів у зв'язку з прийняттям Кримінального процесуального кодексу України : Закон України від 13.04.2012 p. № 4652-VI. URL: https://zakon.rada. gov.ua/laws/show/ru/4652-17/paran29.

10. Про запобігання та протидію домашньому насильству : Закон України від 07.12.2017 р. № 2229-VIII. URL: https://zakon.rada.gov.ua/laws/ show/2229-19.

11. Про внесення змін до Кримінального та Кримінального процесуального кодексів України з метою реалізації положень Конвенції Ради Європи про запобігання насильству стосовно жінок і домашньому насильству та боротьбу з цими явищами : Закон України від 06.12.2017 р. № 2227-VIII. URL: https://zakon.rada.gov.ua/laws/ show/2227-19.

12. Про практику призначення судами кримінального покарання : Постанова Пленуму Верховного Суду України від 24.10.2003 р. № 7. URL: https://zakon.rada.gov.ua/laws/show/v0022700-95.

13. Про деякі питання здійснення кримінального провадження на підставі угод: лист Вищого спеціалізованого суду України з розгляду цивільних і кримінальних справ від 15.11.2012 № 223-1679/0/4-12. URL: https:// zakon.rada.gov.ua/laws/show/v1679740-12. 
14.Про доповнення до інформаційного листа Вищого спеціалізованого суду України 3 розгляду цивільних і кримінальних справ від 15.11.2012 № 223-1679/0/4-12 «Про деякі питання здійснення кримінального провадження на підставі угод» : лист Вищого спеціалізованого суду України з розгляду цивільних і кримінальних справ від 05.04.2013 № 223-558/0/4-13.
URL: https://zakon.rada.gov.ua/laws/show/ v0223740-13.

15. Про практику здійснення судами кримінального провадження на підставі угод : Постанова Пленуму Вищого спеціалізованого суду України з розгляду цивільних і кримінальних справ від 11.12.2015 № 13. URL: https://zakon. rada.gov.ua/laws/show/v0013740-15.

In this article the author highlights the issue of sentencing when concluding and approving reconciliation agreements and plea agreements. The problem of the discretion of the criminal law is distinguished as one of the most important ones. This is reflected through the question of what should be the judicial discretion in criminal matters. The author gives the original definition of the judicial discretion at sentencing process and indicates the regulatory reasons for its existence are. It is suggested that the grounds of the judicial discretion in case of imposing punishments should be considered as criminal sanctions provided by the Criminal Code, authorizing rules, legal facts, which are objectified in legal terms and concepts, and rules of the individualization of punishments. This is very important for improving domestic legislative technology and for editing sentencing rules when conciliation or plea agreements are in place. Private interest, being dominant in the concept of conciliation agreements, was found not to have eliminated the discretionary powers of the judges at sentencing process. The rule on mandatory sentencing specified in the conciliation agreement is denied by the power of judges to carry out a legal analysis of the consensual decision and the possibility not to approve the agreement in established cases. The author's attention is concentrated on the problems of concluding the reconciliation agreements or plea agreements to crimes related to domestic violence, punishment for the set of crimes and the set of sentences, as well as the possibility of concluding and approving such agreements for two-object (multi-objective) crimes. In this paper the scientist analyses the current criminal law, as well as the practice of its application. Appropriate remarks and conclusions have been made regarding to the issue of the optimization of the domestic mechanism of criminal law regulation. This item should be provided by taking into account the tendencies in the practice of application of the criminal law. Particular attention is directed to the problem of specifying the rules of sentencing, as well as the need to develop rules for the appointment of the different criminal measures.

Key words: judicial judgment, set of crimes, set of sentences, domestic violence, two-object crimes. 